\title{
Editor's Report for Volume 127 (2013)
}

Mailing dates for issues in volume 127:

(1) 15 July 2013

(2) 21 October 2013

(3) 4 December 2013

(4) 14 January 2014

In an effort to get caught up in the production schedule, we published 8 issues of The Canadian FieldNaturalist over a period of 14.5 months (3 October 2012 - 14 January 2014). Not surprisingly, submission rates have increased concomitantly over the past few years; a $56 \%$ increase since 2011 . To ensure that we will keep up with the higher number of submissions, we have increased our team of Associate Editors.

The Canadian Field-Naturalist remains an important forum for dispersing science on the distribution, taxonomy, biology, behaviour, ecology, and conservation of species across a broad range of taxa in North America. In volume 127, several new records were published of species of mammals, fish, birds, insects, lichen, plants, plesiosaurian, and ichthyosaur in particular regions of Canada and one new record for the country. Some of the other varied topics include the biology of rare, reintroduced, and invasive species, improved methods for detecting species at risk, impacts of road infrastructure and traffic on wildlife, effects of management actions on the conservation of rare habitats, interspecific interactions, species surveys in under-surveyed regions, and analyses of datasets spanning many decades. As some habitats and species undergo increased pressure from the effects of anthropogenic activity, the utility of CFN to conservation will increase via the provision of scientific information based on field studies. The values that led to the creation of CFN in the 1800 s continue to be relevant today.

Trina Rytwinski, Assistant Editor, edited content, acted as an occasional Associate Editor, and acted as Editor-in-Chief for two months. Elizabeth Morton proofed and edited manuscripts; Wendy Cotie typeset galleys, provided corrections for page proofs, and created pdfs; Roy John, Book Review Editor, requested books for review, selected reviewers, edited submitted reviews, and prepared the new titles listings; Jay Fitzsimmons, Journal Manager, managed financial accounts, issue mailing, and requests for back issues, conducted journal promotion through Twitter and other means, and provided digital content to subscribers. William Halliday prepared the Index with proofreading by Trina Rytwinski and Dan Brunton. Sandra Garland, webmaster of the Ottawa Field-Naturalists' Club, posted tables of contents, abstracts, and pdfs on the CFN section of the OFNC website. Our Associate Editors managed manuscripts, provided reviews and recommendations, and guided authors through the revisions process. The Publication Committee, chaired by Dan Brunton and consisting Paul Catling, Jay Fitzsimmons, Sandra Garland, Tony Gaston, Karen McLachlanHamilton, Frank Pope, and Jeff Saarela effectively guided the operation of the journal. We are indebted to our very dedicated and effective team.

A summary of the distribution of memberships in the Ottawa Field-Naturalists' Club and subscribers to The Canadian Field-Naturalist for 2013 is provided in Table 1. The number of articles and notes in Volume 127 is summarized in Table 2 by topic; totals for book reviews and new titles is given in Table 3; and the distribution of content by page totals per issue is provided in Table 4. Manuscripts (excluding book reviews, notices and reports) submitted to The Canadian FieldNaturalist totalled 84 in 2013. Of these, 73 were accepted for publication, and 30 were published in volume 127, along with 16 manuscripts submitted in 2012 and revised in 2013. A total of 25 Articles, 18 Notes, 3 Tributes, and 3 Essays were published in 2013.

The following Associate Editors managed, assessed and reviewed manuscripts published in volume 127 (number of manuscripts in parentheses): R. Anderson, Canadian Museum of Nature, Ottawa ON (4); C. Callaghan, Luskville QC (3); P. M. Catling, Agriculture and Agri-Food Canada, Ottawa ON (3); F. R. Cook, Emeritus Research Associate, Canadian Museum of Nature, Ottawa ON (5); J. Foote, Algoma University, Sault Ste. Marie ON (4); S. Jung, Yukon Government, White-

TABLE 1. The 2013 circulation of The Canadian Field-Naturalist (2012 in parentheses). Compiled by Jay Fitzsimmons from mailing list for 127(4).

\begin{tabular}{|c|c|c|c|c|c|c|c|c|}
\hline Subscriber Type & \multicolumn{2}{|c|}{ Canada } & \multicolumn{2}{|c|}{ USA } & \multicolumn{2}{|c|}{ Other } & \multicolumn{2}{|c|}{ Total } \\
\hline \multicolumn{9}{|l|}{ Memberships } \\
\hline Family \& Individual & 89 & (89) & 8 & (8) & 1 & (1) & 98 & (98) \\
\hline \multicolumn{9}{|l|}{ Subscriptions } \\
\hline Individual & 79 & $(81)$ & 28 & $(30)$ & 3 & (3) & 110 & (114) \\
\hline Institutional & 127 & $(122)$ & 159 & (164) & 28 & (27) & 313 & (314) \\
\hline Total & 295 & $(292)$ & 195 & $(202)$ & 32 & $(31)$ & 522 & $(525)$ \\
\hline
\end{tabular}


TABLE 2. Number of research and observation articles and notes published in The Canadian Field-Naturalist, Volume 127 , by major field of study.

\begin{tabular}{lccr}
\hline \hline Subject & Articles & Notes & Total \\
\hline Mammals & 7 & 7 & 14 \\
Birds & 6 & 5 & 11 \\
Amphibians and Reptiles & 1 & 1 & 2 \\
Fish & 2 & 1 & 3 \\
Plants & 3 & 2 & 5 \\
Insects & 2 & 2 & 4 \\
Other & 4 & 0 & 4 \\
\hline Total & 25 & 18 & 43 \\
\hline \hline
\end{tabular}

TABLE 3. Number of reviews and new titles published in the Book Review section of The Canadian Field-Naturalist, Volume 127, by topic.

\begin{tabular}{lcc}
\hline \hline & Reviews & New Titles \\
\hline Zoology & 23 & 47 \\
Botany & 3 & 4 \\
Environment & 4 & 2 \\
Miscellaneous & 7 & 28 \\
Children & 1 & 0 \\
\hline Total & 38 & 81 \\
\hline \hline
\end{tabular}

horse YT (3); D. F. McAlpine, New Brunswick Museum, St. John NB (5); D. W. Nagorsen, Mammalia Biological Consulting, Victoria BC (5); C. Renaud, Canadian Museum of Nature, Ottawa ON (3); T. Rytwinski, Carleton University, Ottawa ON (3); J. Saarela, Canadian Museum of Nature, Ottawa ON (7).

The following referees reviewed manuscripts published in volume 127 (number of manuscripts reviewed $>1$ in parentheses): Becky Abel, The Trumpeter Swan Society, Plymouth MN; Ken Abraham, Ontario Ministry of Natural Resources, Peterborough ON; Paul Abram, Carleton University, Ottawa ON; Jim Atkinson, University of Guelph, Guelph ON; Shannon Berch, BC Ministry of Environment, Victoria BC; Sean Blaney, Atlantic Conservation Data Centre, Sackville NB; Edward Bork, University of Alberta, Edmonton AB; Ernie Brodo, Canadian Museum of Nature, Gatineau QC; Ronald J. Brooks, University of Guelph (retired), Guelph ON; Dan Brunton, Ottawa ON; Angela Burkinshaw, Alberta Environment and Sustainable Resource Development, Red Deer AB; Naomi Cappuccino, Carleton University, Ottawa ON; Kevin Cash, Environment Canada, Ottawa ON; Dr. Stephen Clayden, New Brunswick Museum, Saint John NB; Philip A. Cochran, Saint Mary's University of Minnesota, Winona MN; Daniel Cristol, The College of William \& Mary Williamsburg VA; Dr. Rick A. Cunjak, University of New Brunswick, Fredericton NB; Fredrik Dalerum, University of Pretoria, Pretoria South Africa; Margaret F. Docker, University of Manitoba, Winnipeg MB; Erica Dunn, scientist emeritus, Environment Canada,
TABLE 4. Number of pages per section published in The Canadian Field-Naturalist, Volume 127 (2013), by issue.

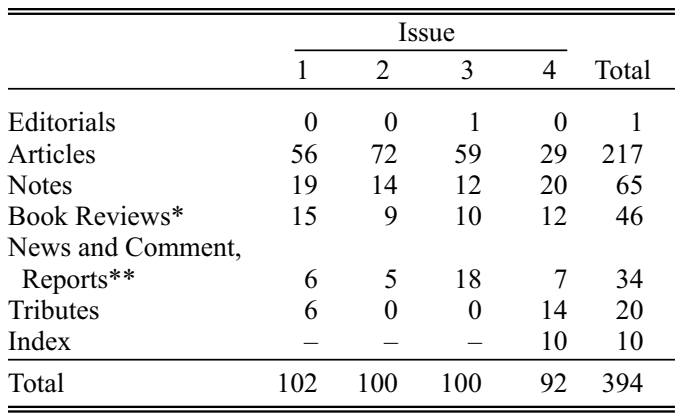

*Includes reviews and new titles listings

**Includes CFN Editor's report, Minutes of the OFNC Annual Business Meeting, and OFNC Awards report.

Ottawa ON; Tony Erskine, Sackville NB (2); Kris Everatt, University of Pretoria, Pretoria South Africa; Lenore Fahrig, Carleton University, Ottawa ON; Dianne Fahselt, University of Western Ontario, London ON; Jennfier Foote, Algoma University, Saulte Ste. Marie ON; Jan Freiwald, University of California, Santa Cruz CA; Marcel Gahbauer Stantec, Montreal QC; John A. Gilhen, Nova Scotia Museum of Natural History, Halifax NS; Steve Hager, Augustana College; Rock Island IL; Sarah Hambleton, Agriculture and Agri-Food Canada, Ottawa ON; Mark Hanson, Fisheries and Oceans Canada, Moncton NB; Lee Hastie, University of Aberdeen, Aberdeen Scotland; Mark Hipfner, Environment Canada, Delta BC; Howard M. Huynh, Texas Tech University, Lubbock TX; Lawrence Igl, U.S.G.S. Northern Prairie Wildlife Research Center, Jamestown ND; Danny Ingold, Muskingum University, New Concord $\mathrm{OH}$; Todd Katzner, West Virginia University, Morgantown WV; Charles Krebs, Professor Emeritus, University of British Columbia, Vancouver BC (2); Karl Larsen, Thompson Rivers University, Kamloops BC; Cori Lausen, Wildlife Conservation Society Canada, Kaslo BC; Zoe Lindo, University of Western Ontario, London ON; Eric Lofroth, Victoria BC; Scott McBurney, Atlantic Veterinary College, University of Prince Edward Island, Charlottetown PEI; Dr. Nick McCann, Minnesota Zoo, Apple Valley MN; Dave Mech, University of Minnesota, St. Paul MN; Dr. David A. Methven, University of New Brunswick, Saint John NB; Randall Miller, New Brunswick Museum, St. John NB; James Miskelly, Royal BC Museum, Victoria BC; Ron Moen, University of Minnesota, Duluth MN; Eric Moise, University of Western Ontario, London ON; Anders Pape Møller, Université Paris-Sud, Orsay Cedex France; Ralph Morris, Brock University (retired), St. Catharines ON; Marion Munroe, Nova Scotia Provincial Museum, Halifax NS; Jan Murie (retired), University of Alberta, Edmonton AB; Dr. Clay Nielson, Southern Illinois University, Carbondale IL; Michael Oldham, Ontario Ministry of Natural Resources, Peter- 
borough ON (3); Dr. Jack Parmalee, Agriculture and Agri-Food Canada, Ottawa ON; Brent Patterson, Ontario Ministry of Natural Resources, Peterborough ON (2); Brian Peer, Western Illinois University, Macomb IL; Paul M. Peterson, National Museum of Natural History, Smithsonian Institution, Washington DC; Roger Powell, North Carolina State University, Raliegh NC; Dr. Gilbert Proulx, Alpha Wildlife Research \& Management Ltd., Sherwood Park AB; Rick Rosatte, Ontario Ministry of Natural Resources, Peterborough ON; Claude Samson, Parks Canada, Quebec City QC; Gautam Sarath, USDA, Lincoln NE; B. Christian Schmidt, Canadian Food Inspection Agency, Ottawa ON; Cory Sheffield, Royal Saskatchewan Museum, Regina SK; Dr. Becky Sjare, Fisheries and Oceans Canada, St. John's NL; Dr. Rick Starr, Moss Landing Marine Laboratory, Moss Landing CA; David Strayer, Cary Institute of Ecosystem Studies, Millbrook NY; Don Sutherland, Natural Heritage Information Centre, Ontario Ministry of Natural Resources, Peterborough ON; Zachary A. Sylvain, Colorado State University, Fort Collins CO; Dr. John Therhane, University of New Brunswick, St. John NB; Karen Vanderwolf, New Brunswick Museum, St. John NB, and Canadian Wild- life Federation, Ottawa ON; David Walter, Royal Alberta Museum, Edmonton AB; Dr. Jane Watson, Vancouver Island University, Nanaimo BC; Wayne Weller, Niagara Falls ON; Jim Wilson, Saint John NB; Linda Wires, University of Minnesota, Duluth MN; Graham Young, Manitoba Museum, Winnipeg MB.

The journal was printed at Gilmore Printers, Ottawa. Thanks to Gilmore for overseeing production and printing. I am grateful to President Fenja Brodo and Council of the Ottawa Field-Naturalists' Club for their support of the journal. I am also grateful to all of the individual subscribers and authors who encouraged our team as we strive to provide a high-quality scientific journal on natural history. A special thank you to Liz Morton for her years of service as copy editor, and to Leslie Cody for producing the Index. Finally, we thank our families for being patient and supportive throughout many evenings and weekends of working on the journal.

CAROLYN CALLAGHAN
Editor in Chief
and
TRINA RYTWINSKI
Assistant Editor

